\title{
Nurses' Perception, Knowledge and Information Sources on Climate Change and Health at Dow University Hospital Karachi
}

\author{
Nazeer Ali Buriro, Sheh Mureed, Ramesh Kumar, Faheem Ahmed, \\ Khadim Hussain, Amir Fatima
}

\section{ABSTRACT}

OBJECTIVE: To assess the knowledge, perception and information sources of nurses about climate change.

METHODOLOGY: A cross sectional study conducted with total number of 105 respondents and duration of 03 months of 2016 at Dow University Hospital Karachi. Study population consisted of nurses and nursing management. Data collected through structured questionnaire. Data was analyzed using frequencies, percentages and associations. Institutional Review Board by Health Services Academy Ethically approved this study. Written consent from participants was taken prior to collect the data.

RESULTS: Most of the nurses $96(94.4 \%)$ considered that air pollution affects their health. $74(70.5 \%)$ were known flooding as one of the adverse effects of climate change, academic qualification age and designation shown association at $\alpha=0.05$ and $\mathrm{Cl}: 95 \%$. Over than $78 \%$ stated that social media was source of their information. The second most source was $67.6 \%$ national or international media.

CONCLUSION: Majority of the nurses has insufficient knowledge and weak perception regarding adverse health effects of climate change, main sources of information were social media. Nurses knowledge can be enhance through in-house trainings and up gradation of the nursing curriculum.

KEYWORDS: (Climate change, Adverse health effects, Nurse's perception, Source of information, Heat waves)

This article may be cited as: Buriro NA, Mureed S, Kumar R, Ahmed F, Hussain K, Fatima A. Nurses' Perception, Knowledge and Information Sources on Climate Change and Health at Dow University Hospital Karachi. J Liaquat Uni Med Health Sci. 2018; 17(04):265-71. doi: 10.22442/jlumhs.181740590

\section{INTRODUCTION}

Climate change can be defined as a long time change in the figures of the weather (including its normal values). It could show up as a change in climate than normally expected average values for temperature and precipitation for a given place and time of year, from one decade to the next. Climate change effects human health directly or indirectly ${ }^{1}$. Quite recently, considerable attention has been paid to climate change and has become an important target of Sustainable Development Goals (SDGs). According to World Health Organization (WHO) Climate change is the utmost health danger of the 21st Century. Increasing temperatures and more risky weather events affect lives directly, increase transmission and spread of infectious diseases, and are challenge to the social and environmental determinants of health. From 2030 to 2050, due to climate change it is predicted that about 250,000 human lives will be lost every year ${ }^{2}$. July 2016 was the warmest month in 136 calendar years in its modern record keeping system. The next decade is likely to see further much development in climate change worldwide, the Climate change is placed at Goal 13 of SDG and urgent action is needed to combat climate change and its impacts ${ }^{3}$. Pakistan is the one of top 10 high risk countries in the world in term of climate change adverse effect vulnerability because of its high rate of poverty and its mostly agricultural population. Pakistan climate change policy has become an integral part of the national budget ${ }^{4}$. In the year of 2014 compensation Pakistan paid to Punjab province an amount of Rs.1.677 billion has been apart from previous years heavy disasters ${ }^{5,6}$. Karachi had experienced a severe heat wave and deaths exceeded 800 during the four days of June 2015 and 2,000 people were died during same month in rest of the Sindh ${ }^{7}$. Climate change is very complex phenomenon that needs an integrated communication system for proper management ${ }^{8}$. It is postulated that nurses can contribute in improving preparedness for health. Nurses therefore need to know about environmental issues global high temperatures may last longer and causing disease and death in people especially vulnerable population and cardiac patients ${ }^{9,10}$. 
Due to increasing adverse health impacts of climate change globally, it is very essential and need timely for nurses to prepare for the present health issues and upcoming challenges. Through governmental and non -governmental organizations, nurses provide health services and support at all stages of health to the population in different situations including natural disasters and extreme weather effects. It is also important for nurses to identify effects on human health directly or indirectly, to recognize gaps in available policies standards and it is vital to explore existing and upcoming strategies. In the field of climate change the health care professionals' awareness especially "nurses" will be useful literature for Pakistan and countries similar demographics. Objectives of this study are to assess perception level, knowledge and determining different sources of information among the nurses from Karachi at Dow University Hospital. Results may provide useful evidence for health care providers, health care institutions, International and national health organizations and hospitals policymakers in the development of policies.

\section{METHODOLOGY}

A cross sectional study conducted at Dow university teaching hospital Karachi, Pakistan. In the 2015 Karachi was the most effected city in Pakistan by heat waves likewise in 2016 and 2017 the high temperature episodes recorded. The duration of the study was from October to December 2016. A structured questionnaire was used for data collection by interviewing the staff nurses working at Dow University Hospital Karachi. Universal sampling technique was used all nurses were approached through their duty roster with hospital management support. Inclusion criteria included the registered nurses of hospital, nursing managers and management official. Those who were on leave, nurse internees and those not registered with Pakistan nursing counsel were excluded. Trained data collectors through structured reliable, validated and pretested tool collected data. Questionnaire was consisted on four portions including sociodemographic section knowledge about environmental and climate related issues section, nurses Perceptions and Information sources. Data was computed using of SPSS 21 version, Descriptive statistics (mean, mode, percentages, frequencies and inter quartile ranges) described in tables. Inferential statistics chi-squire (fisher's exact) to test associations of dependent (perceptions) and independent (demographics) variables at significance level $95 \% \mathrm{p}=$ value $<0.05$. Scores were calculated by computing statements, each statement has 05 score and negative statement has reverse score. Score was added to groups strong and weak perception according to above and below means score. IRB taken from Health Services Academy Islamabad and written consent was obtained from participants. Confidentiality was maintained, approval taken from hospital administration of DUHS.

\section{RESULTS}

A total number of sample size was 105 staff nurses from different departments at Dow university hospital. Participated in the out of study 112 only 02 questioners were uncompleted, 05 were refusals the response rate was $93.7 \%$. According table I Demographic characteristics of 105 respondents (ages 20-60 years) most of these 67(63.8\%) were young adults from $20-30$ years old. About $40(38.1 \%)$ respondents were female. Looking at the level of education, about more than half of the respondents 53 $(50.5 \%)$ were registered nurses having 03 years general nursing with fourth year, second most level of education $43(41.0 \%)$ were post R.N BSc. Nursing level, generic BSN $7(6.7 \%)$ and about $2(1.9 \%)$ were masters holders. Cardiac nursing 29(27.6\%), nurse midwife $21(20 \%)$ community health nursing 24 $(22.9 \%)$, intensive care nursing $12(11.4 \%)$ emergency response and management $7(6.7 \%)$, pediatric nursing $8(7.6 \%)$, others (psychiatric, nursing ward administration and management) 4(3.8\%). Working position of nurses according designation were found about $66(62.9 \%)$ were posted as registered nurse, about $23(21.9 \%)$ were team leaders related to department and $11(10.5 \%)$ were the management personals working as nursing supervisors, managers and nursing superintendent respectively. Forty four percent of respondents 46 had working 1-3 years clinical experience, There were $40(38.1 \%)$ nurses had 4-6 years, $14(13.3 \%)$ had $7-9$ years and about 5 $(4.8 \%)$ respondent had more than 10 years clinical working experience (Table I).

Nurses were asked about environmental issues which they think most important related human health, a huge number of respondent shown air pollution 70 (66.7\%), Flooding $27(25.7 \%)$, heat waves/heat strokes $39(37.2 \%)$, poor waste management $48(45.7 \%)$, traffic/ congestion $42(40 \%)$, climate change 29 $(27.9 \%)$, The hole in the ozone layer $20(19.2 \%)$, using up the earth's resources $9(10.2 \%)$, extinction of species $4(2 \%)$. (Figure I) 
Nazeer Ali Buriro, Sheh Mureed, Ramesh Kumar, Faheem Ahmed, Khadim Hussain, Amir Fatima

Nurses were asked what they know about environmental issues and adverse health effects due to climate change. Most of them 96(94.4\%) respondent shown air pollution have affected their health, $74(70.5 \%)$ were known flooding as one of the adverse impacts of climate change, 59(56.2\%) were known recent floods in this country are due to climate change, $72(68.2 \%)$ think the humans are severely abusing the planet and when they were asked for quality of public transport in local area the 34(32.4\%) rated very poor, 33(31.4\%) poor (Table II).

Respondent's overall perception about health related issues were reported; weak perception 58(55.2\%) strong perception $47(44.8 \%)$ at mean $39.44 \pm 9.52$, ranges from 22-77, towards scientific research concept and infections response measure weak perception $59(56.2 \%)$ has strong perception 46 $(43.8 \%)$ at mean $10.6 \pm 3.6$, ranges from $5-22$, towards strategies and measures for decreasing health effects of climate change, weak perception $65(61.9$ has strong perception $40(38.1 \%)$ at mean $14.1 \pm 5.2$, ranges from 7-35, about the development of scientific research for coping with the adverse health impacts emerging by changing pattern of climate, weak perception $61(58.1 \%)$ has strong perception 44 $(41.9 \%)$ at mean $14.6 \pm 4.1$, ranges from $7-3$ (Table III). The respondent general characteristics and overall perception of climate change and health related issues association tested at significance level $<0.05$; Fisher exact test applied the results presented strong in academic qualification $(p=0.05)$, below undergraduate weak perception $45.3 \%$ and $54.7 \%$ strong perception was seen, at or above under graduation $65.4 \%$ have weak perception and 34.6 have strong perception. Other variables were insignificant (Table IV).

In Table $V$ Participant were asked for sources from they get information about health hazards like floods, heat waves and seasonal incidence of infections, related to climate change. Majority of them more than $78 \%$ stated social media (internet and other social networks) they receive information either always or occasionally the second most source were $67.6 \%$ national or international media (electronic and print), $57.2 \%$ marked government notifications and more than $27 \%$ answered the either never before or just once received. $19 \%$ always and $54.3 \%$ occasionally or sometimes received from institutional seminars, workshops and conferences, $55.1 \%$ School/ college/ university (curriculum), international organizations working for climate change $57.1 \%$ and $55.2 \%$ research articles were marked as source of information.
TABLE I: DEMOGRAPHICS CHARACTERISTICS OF THE RESPONDENTS $(n=105)$

\begin{tabular}{|l|c|c|}
\hline \multicolumn{1}{|c|}{ Characteristics } & Number & Percentage (\%) \\
\hline Age group (years) & 67 & $63.8 \%$ \\
\hline $20-29$ & 30 & $28.6 \%$ \\
\hline $30-39$ & 4 & $3.8 \%$ \\
\hline $40-49$ & 4 & $3.8 \%$ \\
\hline 50 and above & 65 & $61.9 \%$ \\
\hline Gender & 40 & $38.1 \%$ \\
\hline Male & & \\
\hline Female & 53 & $50.5 \%$ \\
\hline Academic qualification & 7 & $6.7 \%$ \\
\hline Registered Nurse & 43 & $41 \%$ \\
\hline Bs.c Generic Nursing & 2 & $1.9 \%$ \\
\hline Post RN, BSc Nursing & & \\
\hline $\begin{array}{l}\text { Masters in Nursing/Pubic } \\
\text { health }\end{array}$ &
\end{tabular}

\section{Specialty}

\begin{tabular}{|l|c|c|}
\hline Cardiac Nursing & 29 & $27.6 \%$ \\
\hline Nurse midwife & 21 & $20 \%$ \\
\hline $\begin{array}{l}\text { Community health Nursing } \\
\text { (Public health) }\end{array}$ & 24 & $22.9 \%$ \\
\hline Intensive care Nursing & 12 & $11.4 \%$ \\
\hline $\begin{array}{l}\text { Emergency response and } \\
\text { management }\end{array}$ & 7 & $6.7 \%$ \\
\hline Pediatrics Nursing & 8 & $7.6 \%$ \\
\hline Others* & 4 & $3.8 \%$ \\
\hline Curre $^{*}$ &
\end{tabular}

Current position (designation)

\begin{tabular}{|l|c|c|}
\hline Nursing superintendent & 2 & $1.9 \%$ \\
\hline Nursing manager & 3 & $2.9 \%$ \\
\hline Nursing supervisor & 6 & $5.7 \%$ \\
\hline Team leader & 23 & $21.9 \%$ \\
\hline Registered nurse & 66 & $62.9 \%$ \\
\hline Years of experience in department \\
\hline $1-3$ & 46 & $43.8 \%$ \\
\hline $4-6$ & 40 & $38.1 \%$ \\
\hline $7-9$ & 14 & $13.3 \%$ \\
\hline $10+$ & 4 & $3.8 \%$ \\
\hline
\end{tabular}

${ }^{*}$ Psychiatric nursing, ward administration and management 


\section{FIGURE I: NURSES RESPONSE RATE TO ENVIRONMENTAL ISSUES THAT CONCERN THE MOST, IN PERCENTAGES $(\mathrm{n}=105)$}

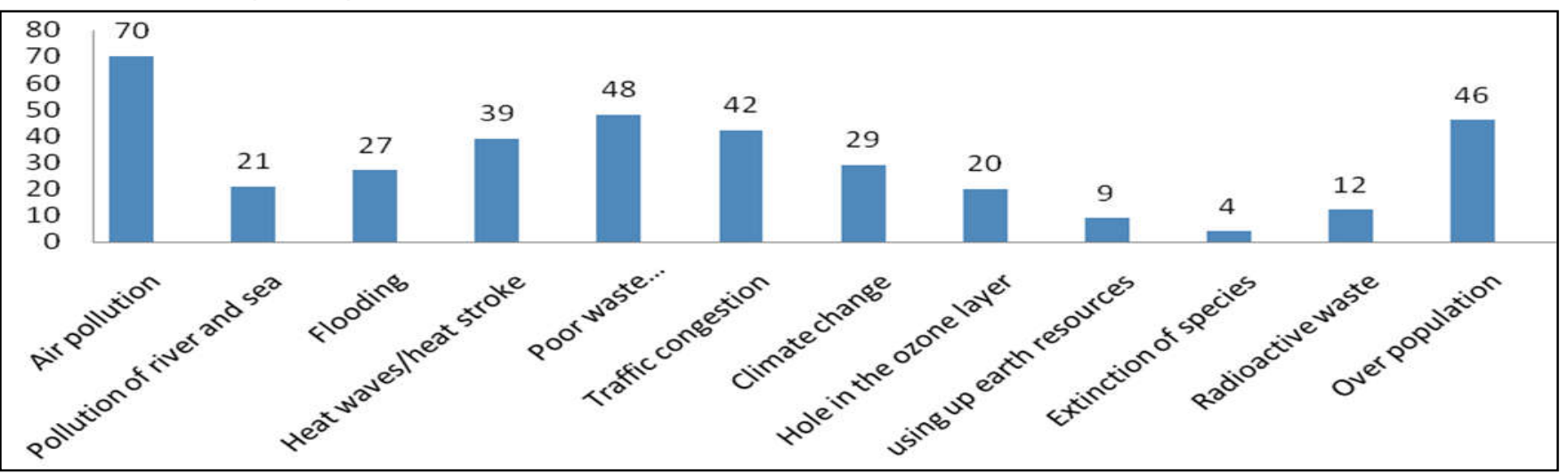

TABLE II: NURSES KNOWLEDGE ABOUT ENVIRONMENTAL ISSUES, CLIMATE CHANGE AND ITS HEALTH IMPACTS $(n=105)$

\begin{tabular}{|c|c|c|c|}
\hline No. & Question & Number & Percentage $(\%)$ \\
\hline 1 & Recent floods in this country are due to climate change? & 59 & 56.2 \\
\hline 2 & Humans are severely abusing the planet? & 72 & 68.6 \\
\hline 3 & The effects of climate change are likely to be catastrophic? & 59 & 56.2 \\
\hline 4 & Pollution ever affected their health? & 96 & 94.4 \\
\hline 5 & Climate change ever affected the health of participant family or friends & 80 & 76.2 \\
\hline 6 & $\begin{array}{l}\text { Apart from effects on people's health, are you aware of any Other effects of climate } \\
\text { change? }\end{array}$ & 65 & 61.9 \\
\hline 7 & Do you know the flooding is one of the adverse impacts of climate change? & 74 & 70.5 \\
\hline 8 & $\begin{array}{l}\text { Have you, in the last } 5 \text { years, experienced any form of flood damage (including to } \\
\text { your home, garden or vehicle)? }\end{array}$ & 45 & 42.9 \\
\hline 9 & Have you heard of "climate change"? & 53 & 50.5 \\
\hline 10 & Do you know the pattern of weather is generally changing? & 57 & 54.3 \\
\hline \multirow[t]{6}{*}{11} & Rated the quality of public transport in your local area & & \\
\hline & Excellent & 2 & 1.19 \\
\hline & Good & 14 & 13.3 \\
\hline & Average & 22 & 21 \\
\hline & Poor & 33 & 31.4 \\
\hline & Very poor & 34 & 32.4 \\
\hline
\end{tabular}

\section{DISCUSSION}

Nurses were known flooding as one of the adverse impacts of climate change in this study. Similar results were seen in a study which was conducted in Sweden argued that nurses require greater knowledge to become involved in and support actions targeting climate change mitigation and to adapt to protect human health and developing nursing students skills to be prepared to cope with conditions arising as a result of climate change ${ }^{9}$. Study findings recommend that inclusion of topics prevention and protecting measures related to climate change health issues in nursing curriculum will be beneficial for nurse's knowledge and practices and will lead to better outcome in disaster condition.

Nurses can be key actors in such efforts. Majority of nurses perceived that changing climate can effect on vulnerable population and they think heat waves are due to extreme weather changing pattern and the 
Nazeer Ali Buriro, Sheh Mureed, Ramesh Kumar, Faheem Ahmed, Khadim Hussain, Amir Fatima

TABLE III: NURSES PERCEPTIONS (OVERALL AND GROUPED) TOWARDS CLIMATE CHANGE AND RELATED HEALTH ISSUES IN PERCENTAGE $(n=105)$

\begin{tabular}{|l|c|c|}
\hline \multicolumn{1}{|c|}{ Perceptions } & $\begin{array}{c}\text { Number } \\
\text { (n=105) }\end{array}$ & $\begin{array}{c}\text { Percentage } \\
\text { (\%) }\end{array}$ \\
\hline Overall perception \\
\hline Weak perception & 58 & 55.2 \\
\hline Strong perception & 47 & 44.8 \\
\hline Median \pm IQR & \multicolumn{2}{|c|}{$(38.0 \pm 11)$} \\
\hline $\begin{array}{l}\text { Towards infectious disease surveillance and scientific re- } \\
\text { search of response measure }\end{array}$ & 59 & 56.2 \\
\hline Weak perception & 46 & 43.8 \\
\hline Strong perception & 65 & 61.9 \\
\hline $\begin{array}{l}\text { Towards strategies and measures for decreasing health } \\
\text { effects of climate change }\end{array}$ & 40 & 38.1 \\
\hline Weak perception & 61 & 58.1 \\
\hline Strong perception & 44 & 41.9 \\
\hline \begin{tabular}{l} 
Towards scientific research in terms of dealing with the \\
health impacts of climate change \\
\hline Weak perception
\end{tabular} \\
\hline Strong perception \\
\hline
\end{tabular}

TABLE IV: ASSOCIATION BETWEEN GENERAL CHARACTERISTICS AND OVERALL PERCEPTION REGARDING CLIMATE CHANGE AND HEALTH ISSUES IN NURSES $(n=105)$

Note: $\mathrm{WP}=$ Weak perception, $\mathrm{SP}=$ Strong perception $=$ Significance level $<0.05 ;{ }^{* *}=$ Fisher ${ }^{*}$ extract

\begin{tabular}{|c|c|c|c|}
\hline \multirow[b]{2}{*}{ Variable } & \multicolumn{3}{|c|}{ Overall perception } \\
\hline & $\begin{array}{c}\text { Weak } \\
\text { perception } \\
(\%)\end{array}$ & $\begin{array}{c}\text { Strong } \\
\text { perception } \\
(\%)\end{array}$ & P-Value \\
\hline \multicolumn{3}{|l|}{ Age in years } & 0.07 \\
\hline 20-39 years & 56.6 & 47.4 & \\
\hline$\geq 40$ years & 87.5 & 12.5 & \\
\hline Gender & & & 0.54 \\
\hline Male & 52.3 & 47.7 & \\
\hline Female & 60 & 40 & \\
\hline \multicolumn{3}{|l|}{ Academic Qualification } & $0.05^{*}$ \\
\hline Below undergraduate & 45.3 & 54.7 & \\
\hline $\begin{array}{l}\text { At or above aca- } \\
\text { demic qualification }\end{array}$ & 65.4 & 34.6 & \\
\hline
\end{tabular}

\begin{tabular}{|c|c|c|c|}
\hline \multicolumn{3}{|l|}{ Speciality } & \multirow[t]{2}{*}{0.49} \\
\hline Public health & 48.9 & 51.1 & \\
\hline Sub-speciality & 58.5 & 41.5 & \\
\hline $\begin{array}{l}\text { Intensive and } \\
\text { emergency care }\end{array}$ & 63.2 & 36.8 & \\
\hline \multicolumn{3}{|c|}{ Current department (area of work) } & 0.71 \\
\hline $\begin{array}{l}\text { Intensive care } \\
\text { Nursing }\end{array}$ & 55.2 & 44.8 & \\
\hline General Ward & 50 & 50 & \\
\hline Nursing management & 61.9 & 38.1 & \\
\hline \multicolumn{3}{|c|}{ Year of experience in this department (in years) } & 0.30 \\
\hline$\leq 6$ years & 52.3 & 47.7 & \\
\hline$\geq 7$ years & 68.4 & 31.6 & \\
\hline \multicolumn{3}{|c|}{ Current Position (designation) } & 0.10 \\
\hline Upper tear & 81.8 & 18.2 & \\
\hline lower tear & 52.1 & 44.8 & \\
\hline
\end{tabular}

TABLE V: SOURCE OF INFORMATION

REGARDING CLIMATE CHANGE AND ITS HEALTH IMPACTS FOR NURSES IN PERCENTAGE $(n=105)$

\begin{tabular}{|l|c|c|c|c|c|}
\hline \multicolumn{1}{|c|}{ Sources } & Always & $\begin{array}{c}\text { Occa- } \\
\text { sionally }\end{array}$ & $\begin{array}{c}\text { Some } \\
\text { time }\end{array}$ & $\begin{array}{c}\text { Just } \\
\text { once }\end{array}$ & Never \\
\hline $\begin{array}{l}\text { Government } \\
\text { notifications }\end{array}$ & $34.3 \%$ & $22.9 \%$ & $15.2 \%$ & $11.4 \%$ & $16.2 \%$ \\
\hline $\begin{array}{l}\text { Institutional } \\
\text { seminars, } \\
\text { workshops and } \\
\text { conferences }\end{array}$ & $19 \%$ & $25.7 \%$ & $28.6 \%$ & $18.1 \%$ & $8.6 \%$ \\
\hline $\begin{array}{l}\text { School/ college/ } \\
\text { university } \\
\text { (curriculum) }\end{array}$ & $27.6 \%$ & $27.6 \%$ & $22.9 \%$ & $18.1 \%$ & $3.8 \%$ \\
\hline $\begin{array}{l}\text { National or } \\
\text { International } \\
\text { Media } \\
\text { (electronic and } \\
\text { print) }\end{array}$ & $32.4 \%$ & $35.2 \%$ & $22.9 \%$ & $6.7 \%$ & $2.9 \%$ \\
\hline $\begin{array}{l}\text { Social media } \\
\text { (internet and } \\
\text { other social } \\
\text { networks) }\end{array}$ & $43.8 \%$ & $34.3 \%$ & $18.1 \%$ & $1.9 \%$ & $1.9 \%$ \\
\hline $\begin{array}{l}\text { International } \\
\text { organizations } \\
\text { working for } \\
\text { climate change }\end{array}$ & $29.5 \%$ & $27.6 \%$ & $28.6 \%$ & $10.5 \%$ & $3.8 \%$ \\
\hline $\begin{array}{l}\text { Research } \\
\text { articles }\end{array}$ & $19 \%$ & $36.2 \%$ & $35.2 \%$ & $4.8 \%$ & $4.8 \%$ \\
\hline
\end{tabular}


most at risk population groups are elders and children. Nurses perception was strong about changing pattern of climate effects adversely on health that diseases are sensitive weather change, a huge number believed about increase in vector-borne, food-borne, water-borne and air-borne diseases may be due to global warming. Particular attention is paid in another study suggest that healthcare professionals must be well aware of climate and environmental issues at the global level, such as the potential for more recurrent and lengthy periods of increased temperatures that could raise in illness and mortality among the elder persons and people with heart disease ${ }^{10}$.

Nurse's attitude related to possible adverse effects on health by climate change, most of them believed that infectious diseases are sensitive to changing pattern of climate. Overall nurse's knowledge and perception was weak regarding climate and its adverse effects on health and institutional and government source were lacking $(p=<0.05)$. Studies revealed that health problems related to the spread of vector-borne diseases and food and water shortages due to increased temperatures ${ }^{11,12}$. Another similar study conduct in china at Center for Disease and Control department employees that support our findings as the majority of respondents assumed that due to climate change or extreme weather infectious diseases are very sensitive. Moreover, more than seventy seven percent of the respondents indicated can be growth in vector-borne, food-borne, water-borne and air-borne diseases due to global warming ${ }^{13}$.

This study found positive associations with perception regarding health effects of climate change were seen in nurse's designation management group, education level shown that fresh graduate and young has more knowledge and strong perception $(p=<0.05)$. An study results shown strong relationship between the young group of employees from 20-39 nearly all respondents were more to be expected to have faith in that changing of weather at worldwide would increase the incidence of communicable diseases, likewise diseases duration of job and duty place with perception about climate change ${ }^{14}$.

Study described sources of nurses information about adverse health effects of climate change most of them were social media (internet and other social networks) as main source second most was national or international media (electronic and print) and about half said government notifications. Previous studies indicates that mass media communication plays an effective roll in conveying massage of climate change mitigation behaviors and preventive strategies may helpful to communities to protect health. Over the years, a number of media analyses have contributed to the wider study of how climate change risks are constructed by different publics and how such constructions translate into individual or collective action. A lot of actors are engaged in communicating about climate change to a variety of other actors: governments, citizens, communities, NGOs, businesses, international organizations, celebrities, risk communication consultants, and so on ${ }^{14,15}$.

\section{CONCLUSION}

Study results shown majority of the nurses has insufficient knowledge and weak perception regarding climate change and its effects on health. The main sources of information were social media, print and electronic media and government sources. Strong associations between education level of nurses and knowledge and perception regarding adverse health impacts of climate change were seen. Management staff has more understanding of health issues.

\section{REFERENCES}

1. Frumkin $\mathrm{H}$, Hess J, Luber G, Mililay J, McGeehin M. Climate Change: The Public Health Response. Am J Public Health. 2008; 98(3):435-45. doi: 10.2105/ AJPH. 2007. 119362.

2. Dasgupta P. Developing Economy Context for Adaptation Decision-Making. In: Climate Sensitive Adaptation in Health 2016 pp. 35-59. Springer India.

3. Osborn D, Cutter A, Ullah F. Universal Sustainable Development Goals: Understanding the Transformational Challenge for Developed Countries. Universal Sustainable Developmemt Goals 2015. Available from: https:// sustainabledevelopment.un.org/ content/ documents/ 1684SF_-_SDG_ Universality _Report_-_May_2015.pdf

4. UNDP Pakistan. UNDP helps bring climate change into the Federal Budget for 2016-2017. UNDP [Internet]. 2016, June 20. Available from: http://www.pk.undp.org/content/ pakistan/en/ home/presscenter/articles/2016/06/20/undp-helpsbring-climate-change-into-the-federal-budget-for2016-2017.html

5. Lamb HH. Climate: Present, Past and Future (Routledge Revivals): Volume 2; Climatic History and the Future. Taylor \& Francis; 2013.

6. Memon N. Malevolent floods of Pakistan-2010-12, Islamabad. Strengthening Participatory Organization. 2012. Available from: http:// www.spopk.org/spo/index.php/ 2013-08-01-19-2844/flood-chronology/file/97-malevolent-floods-ofpakistan? tmpl= component

7. Imtiaz S, Ur-Rehman Z. Death Toll From Heat Wave in Karachi, Pakistan, Hits 1,000. The New 
York Times. June 25, 2015. Available from: https://www.nytimes.com/ 2015/06/26/world/asia/ karachi-pakistan-heat-wave-deaths.html

8. McCarthy M, Brennan M, De Boer M, Ritson C. Media risk communication-what was said by whom and how was it interpreted. J Risk Research 2008; 11(3):375-394.

9. Anakar A, Nilsson M, Holmner A, Elf M. Nurses' perceptions of climate and environmental issues: A qualitative study. J Adv Nurs. 2015; 71(8): 1883 $-91$.

10. Poumadere M, Mays C, Le-Mer S, Blong R. The 2003 heat wave in France: dangerous climate change here and now. Risk Anal. 2005; 25(6): 1483-94.

11. Neill B. March of the Pint Sized Eco-Nazis: They Moan if you Leave the Lights on, Whine if you don't Recycle and Nag you for not Using
Lead-Free Fuel. What is happening to our children? Daily Mail, November 27, 2008.

12. St Louise M, Hess JJ. Climate change. Impacts on and Implications for Global Health. Am J Prev Med 2008; 35(5): 527-38.

13. Wei J, Hansen A, Zhang Y, Li H, Liu Q, Sun Y, et al. The impact of climate change on infectious disease transmission: perceptions of CDC health professionals in Shanxi Province, China. PLoS One. $2014 ;$ 9(10):e109476.

14. Doyle J. Picturing the Clima(c)tic: Greenpeace and the Representational Politics of Climate Change Communication. Science as Culture. 2007;16(2):129-150.

15. Nerlich B, Koteyko N, Brown B. Theory and language of climate change communication. WIREs Clim Chang. 2010; 1:97-110.

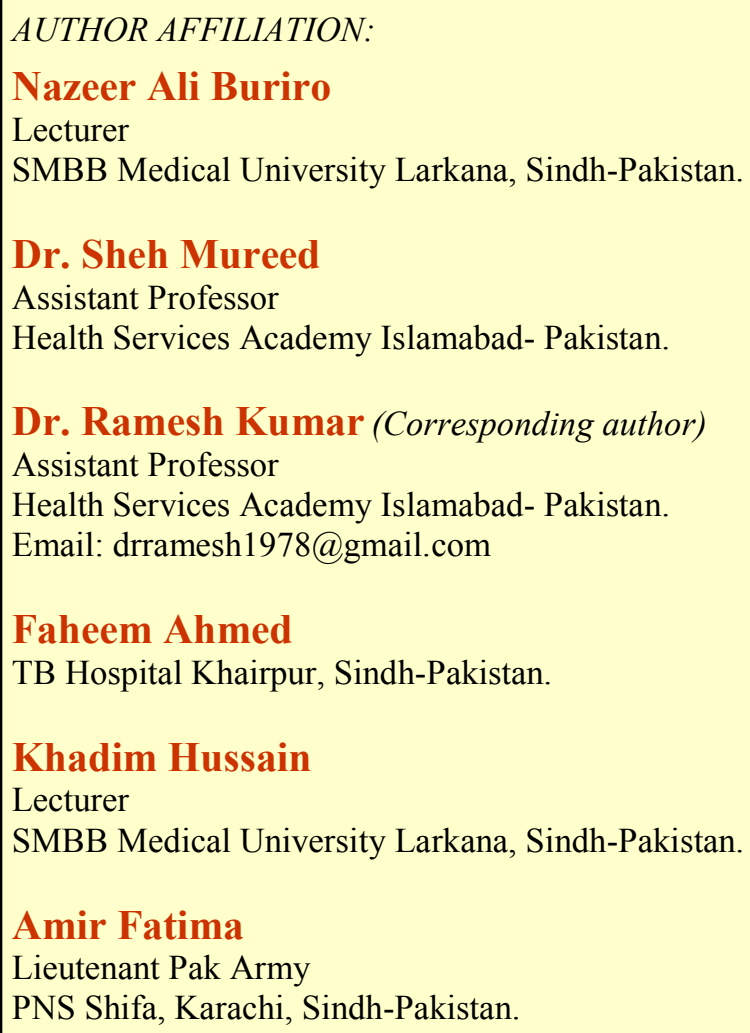

